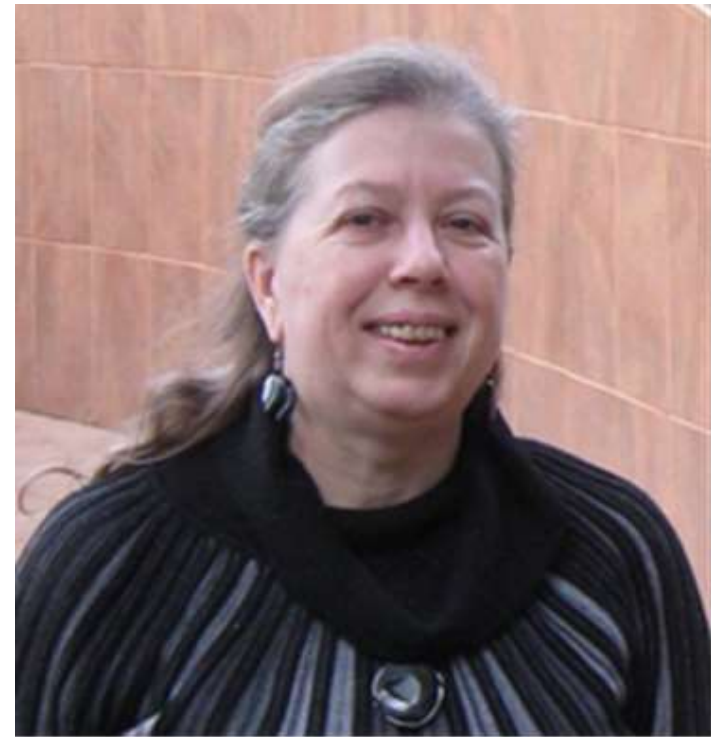

ЧУВІКІНА Наталія

кандидат історичних наук, старший науковий співробітник Національного ботанічного саду імені М.М. Гришка

НАН України, Natachko@ukr.net https://orcid/0000-0002-4069-2406 м. Київ

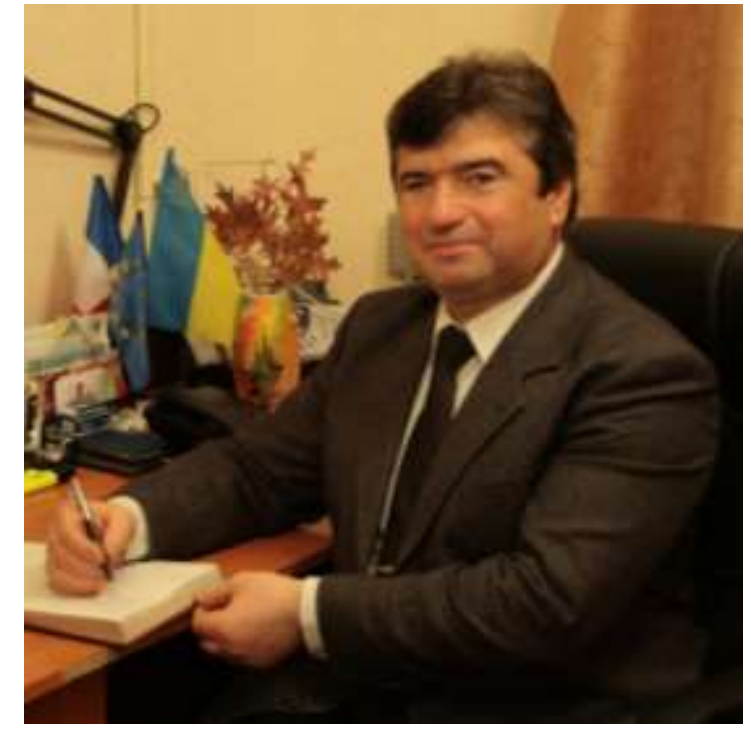

РАХМЕТОВ Джамал

Доктор сільськогосподарських наук, професор, заступник директора 3 наукової роботи, завідувач відділом культурної флори Національного ботанічного саду імені М.М. Гришка НАН України, rjb2000.16@gmail.com https://orcid/ 0000-0001-7260-3263

м. Київ

\title{
НАУКОВО-ОРГАНІЗАЦІЙНА ДІЯЛЬНІСТЬ ПРОФЕСОРА
}

\section{Ю.А. УТЕУША В НАЦІОНАЛЬНОМУ БОТАНІЧНОМУ САДУ ІМЕНІ М.М. ГРИШКА НАН УКРАЇНИ (ДО 110 РІЧЧЯ ВІД ДНЯ}

\section{НАРОДЖЕННЯ)}

Досліджено науково-організачійну

діяльність доктора сільськогосподарських наук, професора Юрія Адольфовича Утеуша (19112001). У дослідженні були використані історико-науковий та джерелознавчий методи. Виділено етапи творчої роботи Ю.А. Утеуша у Центральному республіканському ботанічному саду (ЦРБС) АН УРСР (нині - Національний ботанічний сад (НБС) імені М.М. Гришка НАН України). Хоча вчений прийшов до ЦРБС досвідченим вченим, кандидатом сільськогосподарських наук, найбільш значні наукові досягнення, які принесли йому визнання не лише в Україні, але ци далеко за ї̈ межами, відбулися під час його роботи у ботанічному саду. Перший, етап (1969-1981) - організація роботи створеного ним відділу нових культур. Підсумком иъього етапу став захист Ю.А. Утеушем 
докторської дисертачиї, в якій було розроблено наукові основи системи заходів щцодо додаткового виробництва кормової маси та рослинного протеїну в умовах України, щзо сприяло розвитку нового перспективного напряму в теорії та практииі рослинництва. Під час другого етапу (1981-початок 1990-х рр.)вчений активно прачював над підвищенням ККД сонячної енергї̈, вивчаючи можливості використання озимих та ярих високопродуктивних культур у проміжних посівах, а також нових багаторічних культур. Найважливіший підсумок роботи третього етапу наукової діяльності Ю.А. Утеуша (з початку 1990 р. до останніх днів життя) - че світове визнання. Величезний досвід дозволив Юрію Адольфовичу підвести підсумки інтродукиії кормових рослин, теоретично та практично обтрунтувати уведення нових культур $у$ сільськогосподарське виробниитво. Під керівництвом Ю.А. Утеуша відділ нових культур НБС імені М.М. Гришка НАН Украӥни досяг значних успіхів.

Ключові слова: Ю.А. Утеуш, інтродукиія сільськогосподарських культур, селекиія, Національний ботанічний сад імені М.М. Гришка НАН України

\section{SCIENTIFIC AND ORGANIZATIONAL ACTIVITY OF PROFESSOR}

YU.A. UTEUSH IN THE M.M. GRYSHKO NATIONAL BOTANICAL

\section{GARDEN, NATIONAL ACADEMY OF SCIENCES OF UKRAINE (TO THE 110TH ANNIVERSARY OF HIS BIRTH)}

The scientific and organizational activity of Agricultural Sciences Doctor, Professor Yuri Adolfovich Uteush (1911-2001) has been studied. Historical-scientific and source-based methods were used in the research. The stages of Yu. A. Uteush's work in the Central Republic Botanical Garden (CRBG) of the Academy of Sciences of the Ukrainian SSR (now - M.M. Gryshko National Botanical Garden (NBG) of the National Academy of Sciences of Ukraine) are highlighted. The scientist came to the CRBG as an experienced researcher, candidate of agricultural sciences but the most significant scientific achievements, which brought him recognition not only in Ukraine but also far beyond its borders, is the result of his work in the Botanical Garden. The first stage (1969-1981) was the organization of the work in the Department of New Cultures established by him. The finish of this stage was the doctoral dissertation of $Y u$. A. Uteush. The dissertation deals with the scientific basis of a system of measures for growing additional plant mass and vegetable protein production for forage under the Ukraine condition. This became the contribution to the development of a new promising direction in the theory and practice of crop production. During the second stage (1981-early 1990s), the scientist actively worked on the efficient use of solar energy for crop cultivation, studying the possibilities of using winter and spring high-yielding cultures as intermediate crops, 
as well as new non-traditional perennial plants. The most important result of the third stage (from the beginning of 1990 to the last days of his life) of Doctor Uteush scientific activity is his world recognition as a great scientist. Extensive experience allowed Professor Uteush to summarize the work on forage plant introduction, theoretically and practically justify the new crop introduction in agriculture. The Department of New Cultures in M.M. Gryshko NBG of the NAS of Ukraine has achieved significant success under the leadership of Yu. A. Uteush.

Key words: Yu. A. Uteush, crop introduction, selection, M.M. Gryshko National Botanical Garden of NAS of Ukraine

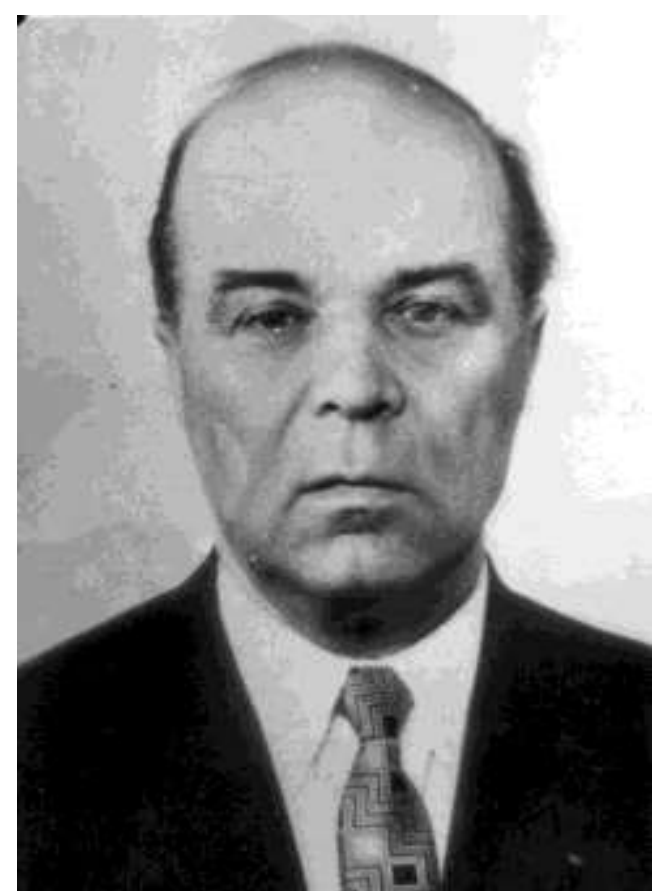

Рис. 1. Ю.А. Утеуш

Постановка проблеми. 1 березня 2021 p. виповнилося $б 110$ років від дня народження Юрія Адольфовича Утеуша (1911-2001) інтродуктора та селекціонера нових кормових культур, доктора сільськогосподарських наук, професора, лауреата премії імені В.Я. Юр'єва, премії Ради Міністрів СРСР, організатора та першого завідувача відділу нових культур Центрального республіканського ботанічного саду (ЦРБС) АН УРСР (нині - відділ культурної флори Національного ботанічного саду (НБС) імені М.М. Гришка НАН України). Незважаючи на низку публікацій про нього, науково-організаційна діяльність та наукова спадщина Ю.А. Утеуша вивчена ще недостатньо.

Аналіз останніх досліджень і публікацій. Життєвий шлях відомого селекціонера Ю.А. Утеуша досліджували О.О. Абрамов, Д.Б. Рахметов, Т.М. Черевченко, О.А. Корабльова, П.А. Мороз [1, 9]. Коротка біографія Ю.А. Утеуша подана у біографічному довіднику «Вони будували сад» $[10$, с. 135-136]. У публікаціях, присвячених історії та науковим досягненням відділу нових культур НБС імені М.М. Гришка НАН України $є$ відомості про організатора цього відділу [2, с. 114-115; 5, с. 75, 77; 6]. Список сортів, 
створених Ю.А. Утеушем наводиться у каталозі сортів рослин, створених у Національному ботанічному саду імені М.М. Гришка НАН України [3, с. 25-26].

Мета статті. Детально вивчити науково-організаційну діяльність та наукову спадщину Юрія Адольфовича Утеуша в НБС імені М.М. Гришка НАН України. У дослідженні були використані історико-науковий та джерелознавчий методи.

Виклад основного матеріалу дослідження. Юрій Адольфович Утеуш народився 1 березня 1911 р. у м. Біла Церква. Після закінчення навесні 1930 р. сільськогосподарської профшколи до вересня цього ж року працював дільничним агрономом Прилуцької окружної зерноспілки. У 1930-1933 рр. вчився у Житомирському сільськогосподарському інституті. Навчання не вдалося закінчити, бо юнак був призваний до лав Червоної армії. Звільнившись у запас, Ю.А. Утеуш працював учителем у середніх школах Вінницької та Житомирської областей, викладачем Стадницького сільськогосподарського технікуму. У липні 1941 р. залишився на окупованій території для виконання завдань органів радянської влади. Після звільнення місцевості від німецьких окупантів, служив у Радянській армії (1943-1945). По демобілізації викладав у навчальних закладах Вінниччини. У 1955 p. повернувся у сільське господарство. Чудовий організатор, працюючи на Українській машинновипробувальній станції керівником дослідного господарства, перетворив його на передову на той час базу для випробування сільськогосподарської техніки. Роботу успішно поєднував 3 навчанням та у 1956 p. закінчив Уманський сільськогосподарський інститут за спеціальністю агроном-рільник $[1,4,10]$.

У 1958-1969 pp. Ю.А. Утеуш працював директором Науковоекспериментальної бази Інституту фізіології рослин i, одночасно, старшим науковим співробітником відділу мікроелементів цього ж інституту, вдало поєднуючи організаційну та наукову роботу. Перші його наукові публікації присвячені новим кормовим культурам та виробництву кормів [4, арк. 50]. Саме тоді відбулося становлення Ю.А. Утеуша як ученого. Крім традиційних культур Юрій Адольфович запропонував використовувати як кормові нові нетрадиційні 
рослини: ріпак (Brassica narus var. Oleifera DC.), гірчицю білу (Sinapis alba L.), сою посівну (Glycine hibrida (Moench.), кормову капусту (Brassica oleraceae L. var. Acephala DC.), чину посівну (Latryrus savitis L.), буркун білий (Melilotus albus Medik). У 1967 p. Ю.А. Утеуш захистив кандидатську дисертацію за темою «Повышение продуктивности кормовых культур на зеленый корм и силос в северной Лесостепи и южном Полесье УССР» і став кандидатом сільськогосподарських наук [4, арк. 43; 6, с. 49].

Однак найбільш значні наукові досягнення, які принесли Юрію Адольфовичу визнання не лише в Україні, але й далеко за їі межами, сталися під час його роботи у Центральному республіканському ботанічному саду (ЦРБС) АН УРСР. У 1968 p. за ініціативою директора ЦРБС АН УРСР академіка А.М. Гродзинського був створений відділ нових культур і впровадження. На посаду завідувача відділу 20 грудня 1968 р. вченою радою ЦРБС було обрано Ю.А. Утеуша. Відділ був створений для впровадження наукових розробок ботанічного саду у народне господарство. Пізніше Юрій Адольфович розробив нові напрями наукової діяльності відділу. Під його керівництвом відділ займався інтродукцією і селекцією кормових ресурсів флори України, експериментальною ботанікою. Відділ нових культур швидко зайняв чільне місце серед установ, які займалися інтродукцією та селекцією нетрадиційних і малопоширених кормових рослин. 3 багатьма профільними установами утворилися творчі зв'язки.

Підсумком першого етапу наукової діяльності Ю.А. Утеуша в ЦРБС стала докторська дисертація «Научные основы возделывания рапса и сурепицы в промежуточных посевах на Украине», захищена у 1981 р. [4, арк. 46; 6, с. 50]. Ним було розроблено наукові основи системи заходів щодо додаткового виробництва кормової маси та рослинного протеїну в умовах України, що сприяло розвитку нового перспективного напряму в теорії та практиці рослинництва. Впровадження у виробництво нових культур, що раніше не використовувалися в умовах України дало можливість суттєво збільшити ККД фотосинтезу та продуктивність орної землі в цілому і стало новим 
перспективним напрямом у кормовиробництві. У цей період ним була уведена в сільськогосподарське виробництво найранньостигліша кормова культура озима суріпиця.

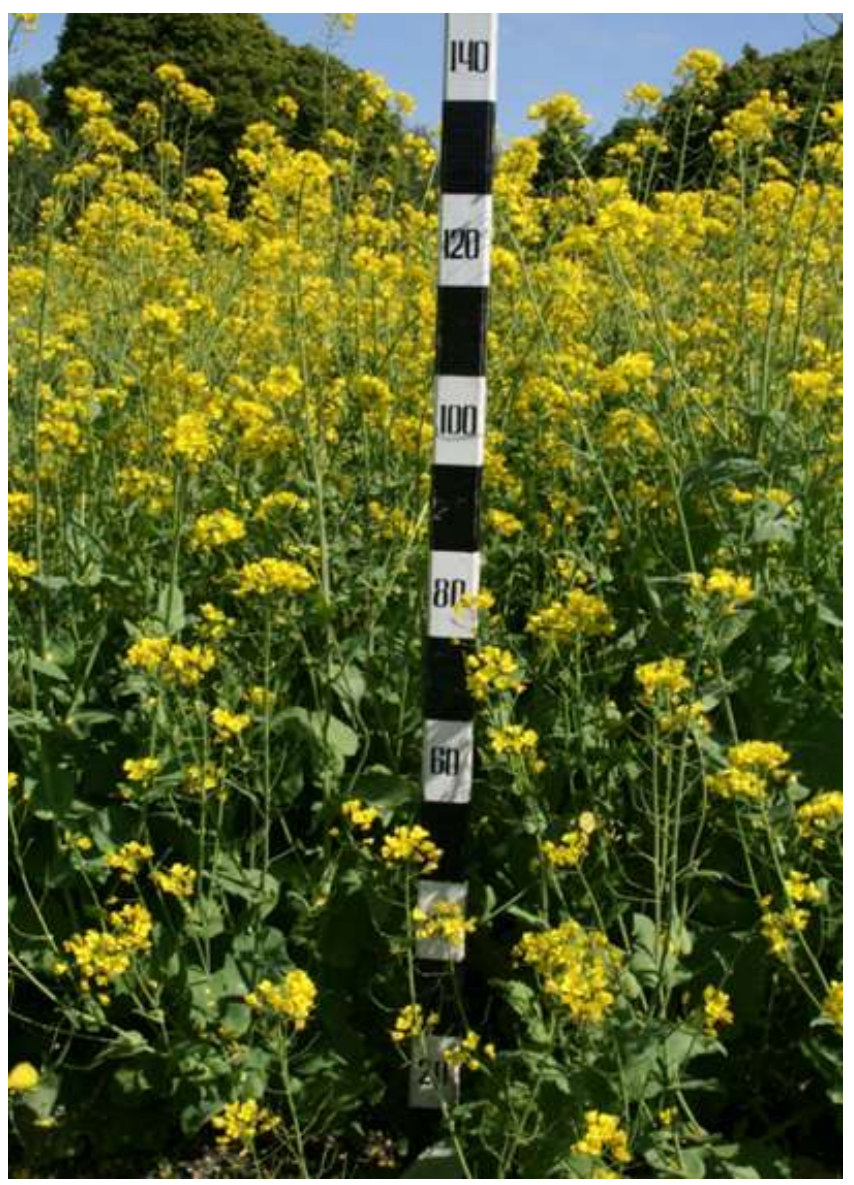

Рис. 2. Суріпиця озима (Brassica campestris f. biennis), фаза квітування

Перший період наукової діяльності Юрія Адольфовича в НБС імені Гришка НАН України можна назвати «бронзовим». Практичною цінністю розробок Ю.А. Утеуша стало використання в умовах України врожаю ріпаку та суріпиці ранньою весною та пізньої осені, що дало можливість скоротити стійловий період утримання худоби на 1,5-2,0 місяці, збільшити продуктивність тваринництва $[9$, с. 6].

Щоб ефективно впроваджувати у виробництво та 3 метою збереження цінних сортів селекції відділу Ю.А. Утеуш організував їх розмноження на площі 40 га на закріпленій сівозміні в науково-дослідному господарстві Академії наук на станції «Глеваха». Для цього під його керівництвом дослідне сільськогосподарське виробництво «Глеваха» було забезпечено технікою, складськими приміщеннями, добривами, кадрами. 


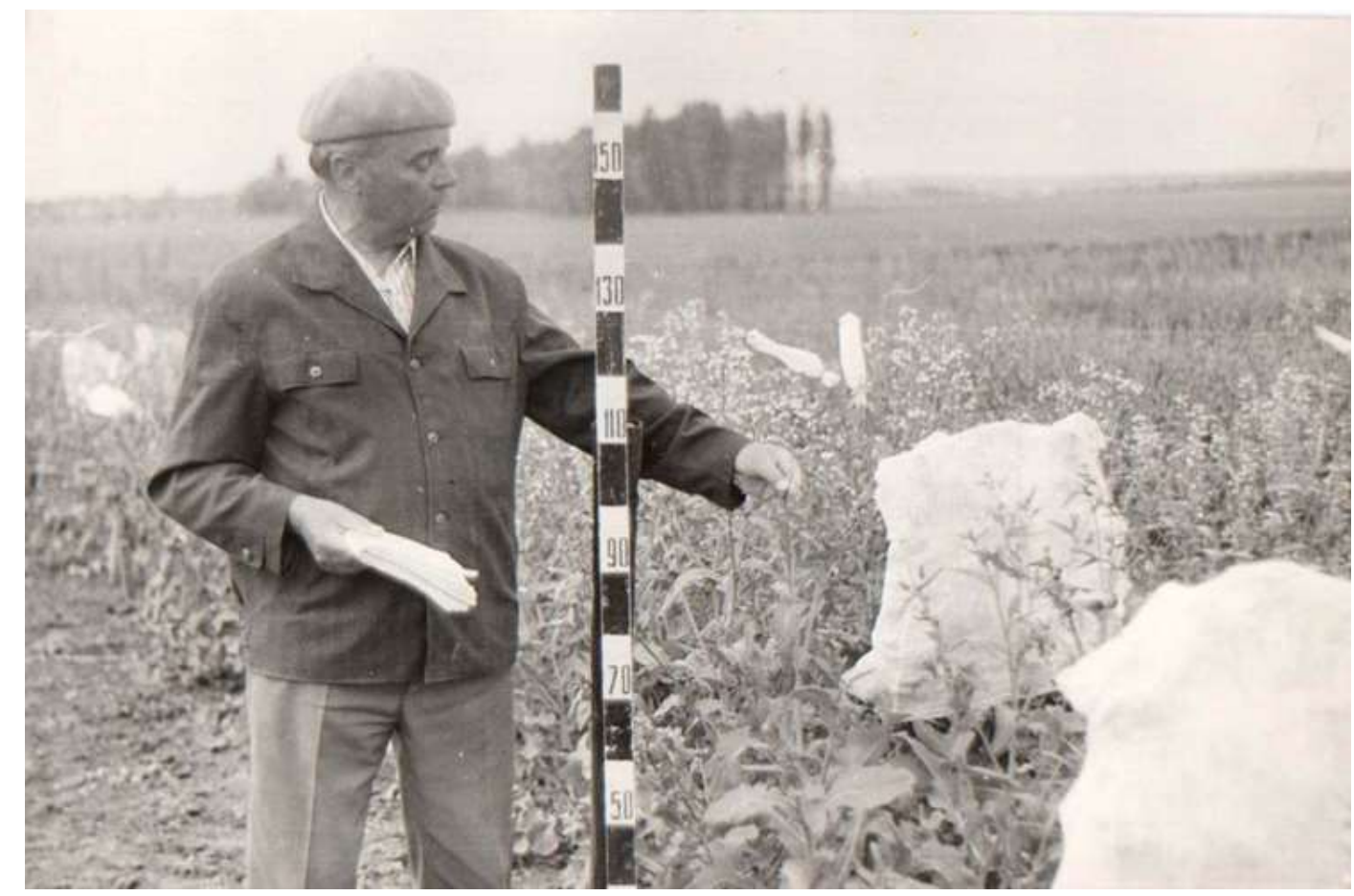

Рис. 3. Ю.А.Утеуш на дослідних ділянках капустяних культур (дослідне господарство НАН України «Глеваха»), друга половина 1970 pp.

Наступний етап наукової діяльності Ю.А. Утеуша від початку 1980-х до початку 1990-х рр. можна назвати «срібним». Під враженням праць К.А. Тімірязєва Юрій Адольфович у захваті цитував важливу думку видатного вченого як теоретичне підгрунтя своєї роботи «Удивительная и не до конца разгаданная тайна «фабрики» растительной клетки и хлорофиллового зерна. Первичное сырье для образования самых сложных органических веществ крахмала, сахара, белков, жиров до предела просто. Это углекислый газ и вода. Энергия для их синтеза одна - солнечная радиация. И, к сожалению, человек творец сверхсложных вычислительных машин, атомных реакторов, космических станций - не может повторить то, что совершает зеленая растительная клетка» $[7$, с. 165]. Зважаючи на це, Ю.А. Утеуш активно працював над підвищенням ККД сонячної енергії. Вивчаючи можливості використання озимих та ярих високопродуктивних культур у проміжних посівах, а також нових багаторічних культур, він довів, що ККД фотосинтезу можна підвищити як мінімум у 1,5-2,0 рази $[6$, с. $51 ; 9$, с. 7]. Разом 3 колегами професор Ю.А. Утеуш проводив масштабну роботу з випробування нових розробок відділу у виробничих умовах. 


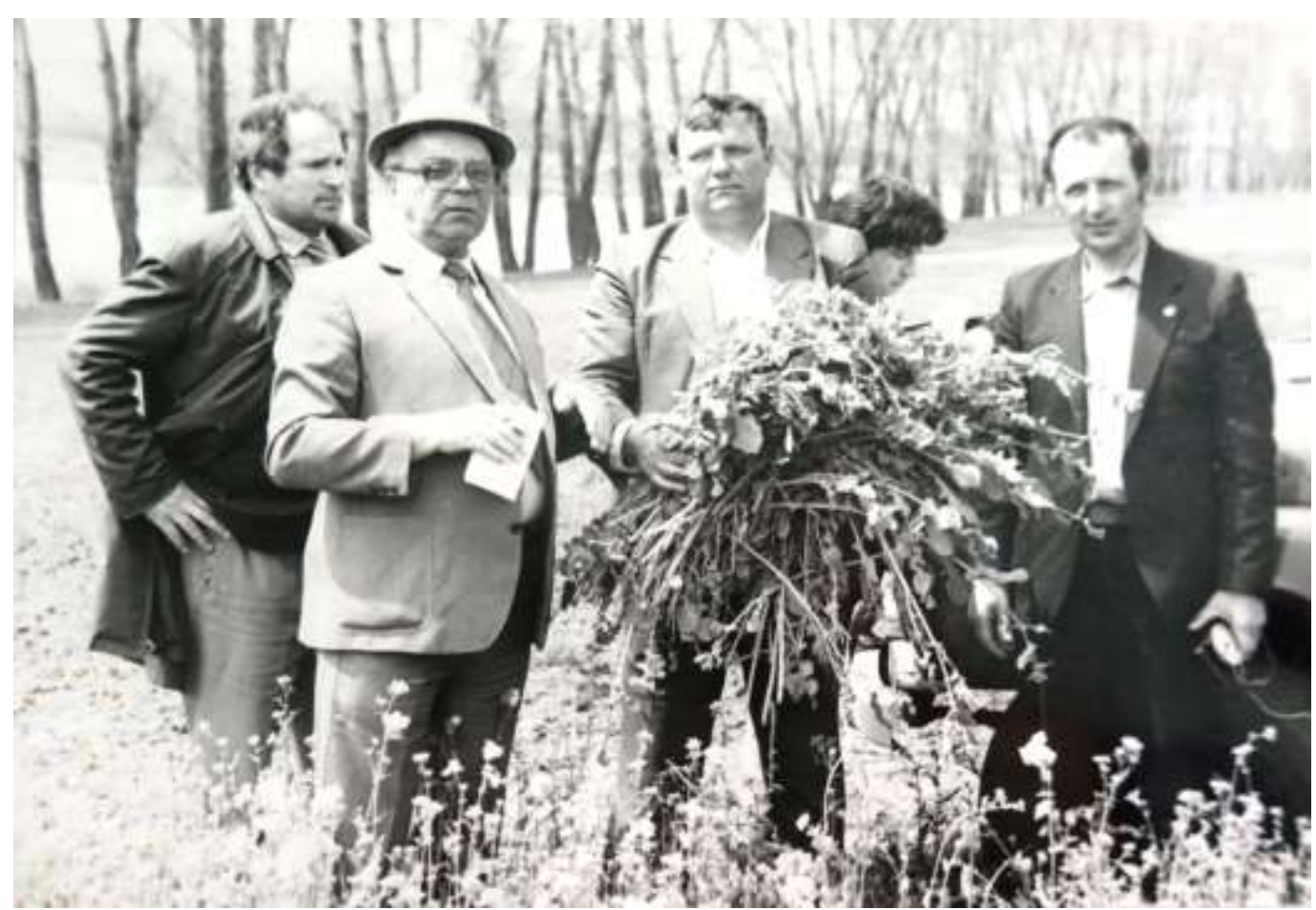

Рис. 4. Апробація посівів суріпиці озимої (сорт Горлиця) у виробничих умовах (Миронівський район Київської області), травень, 1988 р.

Редька олійна (сорт Райдуга), виведена Ю.А. Утеушем та зареєстрована у 1983 р. [3, с. 25], тільки на території України вирощувалася на площі понад 400 га. Пізніше іiі замінив більш ранній та продуктивний сорт Либідь (рік реєстрації - 1995, автор Ю.А. Утеуш) [3, с. 25].

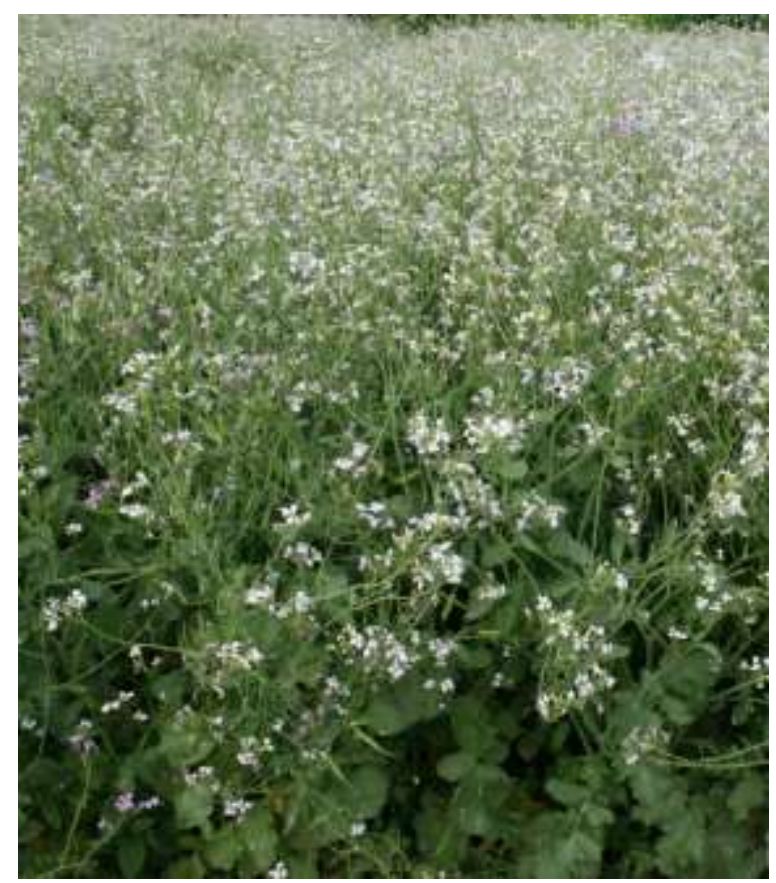

Рис. 5. Редька олійна (Raphanus sativus L. var. oleiformis Pers.), сорт Либідь - фаза квітування-початок плодоношення 
Крім однорічних культур Юрій Адольфович велику увагу приділяв багаторічним високопродуктивним інтродуцентам. В результаті був створений унікальний міжвидовий гібрид щавлів тянь-шанського та шпинатного (Rumex patientia L.xR. tianshanicus A. Los) - сорт Румекс K1.

Величезний досвід дозволив Юрію Адольфовичу розробити для нових кормових рослин основні критерії введення в культуру. Вони включають такі важливі показники, як поїдання худобою, вміст білка, врожайність, насінна продуктивність, інтенсивність вегетації, технологічність, зимостійкість, посухостійкість, стійкість до шкідників та хвороб, конкурентоздатність до бур'янів, екологічна пластичність, економічна доцільність [7, с. 164].

На другому («срібному») етапі сформувалася наукова школа Юрія Адольфовича. Під його керівництвом було захищено 2 докторські та 14 кандидатських дисертацій, що були присвячені найбільш перспективним культурам, серед яких редька олійна, суріпиця і ріпак, сорго багаторічне, сильфій пронизанолистий, щавель гібридний, соняшник бульбистий, свербіга східна, кормові мальви, нові пряно ароматичні та овочеві рослини. Глибоке вивчення морфології, анатомії, фізіології, біохімічного складу нових та маловідомих видів рослин в умовах культури дали змогу Ю.А. Утеушу вивести низку унікальних високопродуктивних сортів. Разом 3 очолюваним ним колективом він інтродукував понад 300 зразків рослин (206 видів, форм та сортів кормових, 98 пряносмакових та 53 малопоширених овочевих рослин. Під його керівництвом виведено понад 40 перспективних сортів, які було впроваджено на площі близько 2 млн га в Україні, Росії, Білорусі, Казахстані, Чехії, Китаї. Ю.А. Утеуш був співзасновником асоціації «Нові культури», яка виступала посередником між наукою і виробництвом. На базі відділу систематично проводилися науково-практичні семінари 3 нових культур для фахівців та спеціалістів.

Найважливіший підсумок роботи останнього, «золотого» етапу наукової діяльності Ю.А. Утеуша (з початку 1990 р. до останніх днів життя) - це світове визнання. Величезний досвід дозволив Юрію Адольфовичу підвести підсумки 
інтродукції кормових рослин, теоретично та практично обгрунтувати введення нових культур у сільськогосподарське виробництво.

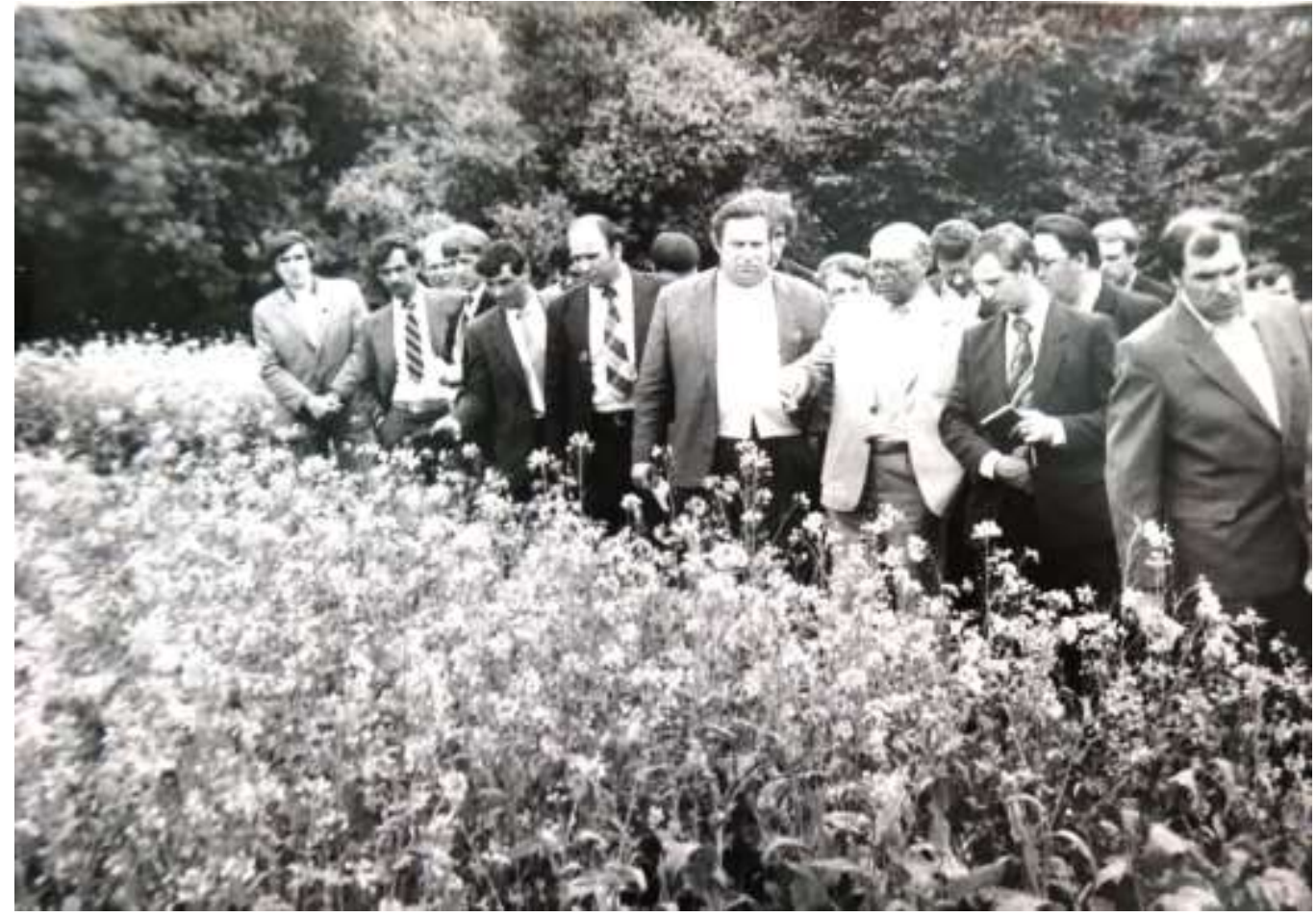

Рис. 6. Ознайомлення спеціалістів агровиробництва з новими розробками відділу, травень, 1987 р.

У 1998 р. Ю.А. Утеуш видав монографію, в якій науково обгрунтував та проаналізував біоекологічні основи інтродукції кормових рослин в умовах лісостепу України [8]. Крім інших критеріїв введення інтродуцентів в культуру він ввів новий - алелопатичну активність та сумарну оцінку інтродуцентів. Це було результатом спільної співпраці з відділом алелопатії рослин.

Юрій Адольфович класифікував та визначив місце малопоширених інтродуцентів у екосистемі, проаналізував біоекологічні основи інтродукції однорічних кормових культур основної та проміжної вегетації, багаторічних інтродуцентів весняно-літньої вегетації.

Важливим підсумком праці Ю.А. Утеуша стало світове визнання. Виведені ним сорти (Румекс ОК-2, Стерх, Горлиця, Золотинка, Стугна-1, Парана) сьогодні вийшли за межі України і успішно впроваджуються за кордоном (у Китаї, Чехії, Казахстані, Польщі, Німеччині). Про них знають у США, Японії та інших країнах. 
Ю.А. Утеуш $є$ автором понад 150 наукових праць, серед яких 6 монографій. 31981 р. по 1988 р. Ю.А. Утеуш був членом консультативнокоординаційної ради при Раді Міністрів України з розвитку сільського господарства. Багато часу він приділяв викладацькій діяльності у ВУЗах України. Організував та провів 5 наукових міжреспубліканських конференцій 3 виданням доповідей. Навіть в останні роки життя, перебуваючи на заслуженому відпочинку, жваво цікавився справами відділу, писав наукові статті, відгуки на автореферати, відповіді на листи фермерів.

Сьогодні колектив відділу культурної флори НБС на чолі 3 професором Д.Б. Рахметовим, зберігаючи історичну спадщину професора Ю.А. Утеуша, досяг значних результатів у розвитку нових наукових напрямів. Відділ став важливим науковим і практичним центром у галузі інтродукції, акліматизації, фітотехнології рослин, селекції та впровадження нових культур і сортів у виробництво. Розроблено біолого-екологічні методи $з$ підвищення родючості грунту та продуктивності агроценозів. Досягнуто значних успіхів у розвитку фундаментальних та прикладних засад фітоенергетики в Україні. Створено унікальні за якісним i кількісним складом колекції енергетичних, пряносмакових, лікарських, ефіроносних, сидеральних, медоносних та інших груп рослин з різних ботаніко-географічних регіонів світу, які нараховують понад 2000 зразків. «Колекційний фонд енергетичних та ароматичних рослин» (понад 1500 зразків) включений до Переліку об'єктів, що становлять Національне надбання.

За наслідками багаторічної інтродукційної та селекційної роботи суттєво збільшено видове (понад 50 нових культур) та сортове різноманіття (понад 100 сортів, створених у відділі, занесено до Державного реєстру сортів рослин України) культурфітоценозів.

Висновки та перспективи подальших досліджень. Доктор сільськогосподарських наук професор Юрій Адольфович Утеуш зробив вагомий внесок у розвиток інтродукції та селекції малопоширених кормових культур. Величезними є також і наслідки його науково-організаційної праці. 
Під керівництвом Ю.А. Утеуша відділ нових культур НБС імені М.М. Гришка НАН України досяг значних успіхів. Наукові здобутки Ю.А. Утеуша потребують подальшого дослідження.

\section{Список використаних джерел та літератури}

1. Абрамов О.О., Рахметов Д.Б., Корабльова О.А. Життєвий шлях відомого вченого селекціонера професора Ю.А. Утеуша. Інтродукиія рослин. 2000. № 34. C. $10-14$.

2. Наукові об’єкти НБС імені М.М. Гришка НАН України, що становлять національне надбання / Д.Б. Рахметов, Н.В. Заіменко, М.Б. Гапоненко, Л.І. Буюн, О.Л. Рубцова, Р.В. Іванніков та ін. Київ: Паливода А.В., 2019. 224 с.

3. Каталог сортів рослин, створених у Національному ботанічному саду ім. М.М. Гришка НАН України /Черевченко Т.М., Рахметов Д.Б., Чувікіна Н.В., Мороз П.А., Гапоненко М.Б. К.: Нора-прінт, 2004. 32 с.

4. Особова справа Ю.А. Утеуша. Фонди музею історії Національного ботанічного саду імені М.М. Гришка НАН України. 91 с.

5. Рахметов Д.Б. Відділ нових культур: минуле, сучасне та майбутнє. Інтродукиія рослин. 2005. № 3. С. 73-87.

6. Рахметов Д.Б. Теоретичні та прикладні аспекти інтродукції рослин в Україні: монографія. К.: «Аграр Медія Груп», 2011. С. 48-54.

7. Утеуш Ю.А. Новые перспективные кормовые культуры. К.: Наук.думка, 1991. $192 \mathrm{c}$.

8. Утеуш Ю.А. Екологія нових кормових інтродуцентів в умовах лісостепу України. К.: Ін-т математики НАН України, 1998. 318 с.

9. Черевченко Т.М., Мороз П.А., Рахметов Д.Б. Профессор У.А. Утеуш ученый интродуктор, селекционер. Інтродукція рослин. 2000. № 3-4. С. 5-9.

10. Чувікіна Н.В., Клименко С.В. Вони будували Сад: Біографічний довідник. К.: Цукор України, 2009. С. 135-136.

\section{References}

1. Abramov O.O., Rakhmetov D.B., Korabl`ova O.A. (2000). Zhittyevij shlyakh vi domogo vchenogo selekczi`onera profesora Yu.A. Uteusha [The life of the famous scientific breeder Professor Yu.A. Uteush]. Introdukczi ya roslin [Plant Introduction]. № 3-4. P. 10-14. [in Ukrainian].

2. (2019). Naukovi` ob'yekti NBS i`meni` M.M. Grishka NAN Ukrayini, shho stanovlyat' naczi onal 'ne nadbannya [Scientific objects of the M.M. Gryshko NBG of the National Academy of Sciences of Ukraine, forming the national heritage] / D.B. Rakhmetov, N.V. Zaimenko, M.B. Gaponenko, L.I. Buyun, O.L. Rubczova, R.V. Ivannikov ta i`n. K.: Palivoda A.V., 2019. 224 p. [in Ukrainian].

3. (2004) Katalog sorti`v roslin, stvorenikh u Naczi`onal'nomu botani`chnomu sadu i`m. M.M. Grishka NAN Ukrayini [Catalog of plant varieties created in the M.M. Grishko National Botanical Garden NAS of Ukraine]. / Cherevchenko T.M., 
Rakhmetov D.B., Chuvikina N.V., Moroz P.A., Gaponenko M.B. K.: Nora-print. 32 p. [in Ukrainian].

4. Osobova sprava Yu.A. Uteusha [Personal file of Yu.A. Uteush]. Fondi muzeyu i`stori yi Naczi`onal’nogo botani`chnogo sadu i`meni M.M. Grishka NAN Ukrayini [Funds of the Museum of History of the M.M. Grishko National Botanical Garden NAS of Ukraine]. $91 \mathrm{p}$.

5. Rakhmetov D.B. (2005. № 3). Vi'ddi'l novikh kul'tur: minule, suchasne ta majbutnye [Department of New Cultures: Past, Present and Future]. I'ntrodukczi ya roslin [Plant introduction]. P. 73-87. [in Ukrainian].

6. Rakhmetov D.B. (2011).Teoretichni` ta prikladni` aspekti i`ntrodukczi yi roslin V Ukrayini : monografi ya [Theoretical and applied aspects of plant introduction in Ukraine: monograph]. K.: «Agrar Medi ya Grup», P. 48-54. [in Ukrainian].

7. Uteush Yu.A. (1991). Novy`e perspektivny`e kormovy`e kul tury` [New promising forage crops]. K.: Nauk.dumka, 192 p. [in Russian].

8. Uteush Yu.A. (1998). Ekologi`ya novikh kormovikh i`ntroduczenti`v v umovakh li`sostepu Ukrayini [Ecology of new fodder introducers in the forest-steppe conditions of Ukraine.]. K.: I'n-t matematiki NAN Ukrayini, 318 p. [in Ukrainian].

9. Cherevchenko T.M., Moroz P.A., Rakhmetov D.B. (2000. № 3-4). Professor Yu.A. Uteush - ucheny`j introduktor, selekczioner [Professor Yu.A. Uteush scientist introducer, breeder]. I'ntrodukczi ya roslin [Plant introduction]. P. 5-9. [in Russian].

10. Chuvikina N.V., Klimenko S.V. (2009). Voni buduvali Sad: Biografichnij dovidnik [They built the Garden: A Biographical Guide]. K.: Czukor Ukrayini. P. 135-136. [in Ukrainian].

\section{Рецензенти:}

Кучер В.I., д.і.н., професор

Коваленко Н.П., д.і.н., с.н.с.

Надійшла до редакції 25.07.2021 р. 